\title{
Article \\ Performance, Risk, and Cost of Capital: Trends and Opportunities for Future CSR Research
}

\author{
Asif Saeed ${ }^{1, *}$ and Robert Sroufe ${ }^{2}$ (D) \\ 1 FAST School of Management, National University of Computer and Emerging Sciences, Lahore 54000, Pakistan \\ 2 Palumbo Donahue School of Business, Duquesne University, Pittsburgh, PA 15282, USA; sroufer@duq.edu \\ * Correspondence: asif.saeed@outlook.com; Tel.: +92-33-3630-9789
}

Citation: Saeed, Asif, and Robert Sroufe. 2021. Performance, Risk, and Cost of Capital: Trends and Opportunities for Future CSR Research. Journal of Risk and Financial Management 14: 586. https:// doi.org/10.3390/jrfm14120586

Academic Editor: Ştefan

Cristian Gherghina

Received: 22 October 2021

Accepted: 29 November 2021

Published: 6 December 2021

Publisher's Note: MDPI stays neutral with regard to jurisdictional claims in published maps and institutional affiliations.

Copyright: (c) 2021 by the authors. Licensee MDPI, Basel, Switzerland. This article is an open access article distributed under the terms and conditions of the Creative Commons Attribution (CC BY) license (https:// creativecommons.org/licenses/by/ $4.0 /)$.
Abstract: The information within this study reviews the financial management literature focusing on proponents and opponents of corporate social responsibility (CSR). We review how CSR affects different areas of corporate finance. This study's core objective is to explore the last 20 years (2000-2019) of CSR top-tier literature to develop and theoretically support CSR and environmental management. Twenty years of publications provide a considerable amount of evidence on CSR's impacts on firm financial characteristics and some paradoxical findings. The majority of our insights support the argument that doing good is good for business. This study also highlights existing gaps in the literature. Based on our findings, we highlight three areas to further explore in the context of CSR and corporate finance: (1) Does CSR improve specific information contents in stock prices? (2) Does CSR mitigate financial distress risk? and (3) Is CSR good for firm trade credit?

Keywords: agency; corporate social responsibility; financial performance; information environment; distress risk; trade credit

\section{Introduction}

In 2015, the United Nations (UN) presented the agenda of Transforming Our World: The 2030 Agenda for Sustainable Development, a plan of action for people, the planet, and prosperity. A total of 193 countries adopted this agenda for sustainable development over the next 15 years, with 17 sustainable development goals (SDGs) associated with 169 targets. Poverty eradication is one of the most significant challenges for United Nations member countries. Of the 197 parties of the UN convention in 2016, 143 ratified the Paris Agreement (member countries resolve to end poverty and hunger everywhere between now and 2030). The primary aim of the Paris Agreement is to "strengthen the global response to the threat of climate change by keeping global temperature rise this century well below 2.0 C above pre-industrial levels, and to pursue efforts to limit the temperature increase even further to 1.50 C" $^{\prime \prime}$ (The Paris Agreement 2016, p. 3 Article 2). In the European context, the main goal of the Europe 2020 strategic plan is for the EU to become a smart, sustainable, and inclusive economy.

While these global agendas provide a proving ground for CSR, we can also recall concerns from some who have said we should be leery of corporate social responsibility (CSR). Some are worried that there is a hidden agenda to CSR. Others are concerned that today's do-good companies and CEOs will end up doing bad things in the future. Other statements against CSR include but are not limited to some saying CSR strategies will hurt companies financially because they are not devoting all their attention to corporate finance and fiduciary responsibility to shareholders to increase profits (Bhandari and Javakhadze 2017). CSR can be a positive or negative opportunity for business decisionmakers depending on the source of information. In this study, we argue that these ongoing global agendas and CSR-based plans are dynamic efforts. We posit that these types of efforts, when viewed through the lens of empirical work in the field, show CSR provides innovative opportunities for financial performance, risk management, and cost of capital. 
To help sort this out, we draw from 20 years of prior literature to assess current trends and look for new insights.

The rest of this paper is as follows. We start with a review of the literature and define key concepts. Section three establishes the ethical arguments for the two opposing views on CSR. The fourth section explains the methods used in this study to review the literature. Section five discusses the CSR literature, three primary insights. The last section covers conclusions and opportunities for future research.

\section{Literature Review}

We next look at why CSR and environmental management are essential to a prosperous future and how the CSR paradigm is defined. The business literature presents several definitions of CSR. The central theme for all CSR definitions involves discretionary expenditures to improve social and environmental conditions (Groening and Kanuri 2016; Mackey et al. 2007; Margolis and Walsh 2003). CSR is defined as involving "actions that appear to further some social good, beyond the interests of the firm and that which is required by law" (McCarthy et al. 2017, p. 280; McWilliams and Siegel 2001, p. 117). For the purposes of this study, and building on the work of prior experts in CSR, we propose the following definition CSR is a firm's volunteer effort to achieve sustainable performance, by managing the social and environmental activities responsibly.

In the last two decades, a new class of socially and environmentally inclined investors and firms' evaluators has emerged: socially responsible investors. Such investors pay attention to both a company's social responsibility and stock performance and consider investing in a socially responsible firm is good for society and as an investment. To attract socially responsible investors, organizations spend more for the betterment of society. Asset managers prefer socially responsible companies, and other stakeholders (e.g., customers, suppliers, governments) are considering companies' CSR efforts. Companies organize different types of activities to support society. For example, Microsoft employees donated $\$ 1$ billion in 30 years (1983-2012), and the company matched the amount through an employee giving campaign (Adhikari 2016). In 2015, Microsoft employees donated \$125 million to 18,000 schools and nonprofit organizations around the world. Google directly donates $1 \%$ of its profit for charitable purposes based on its "do no evil" policy. On the same social responsibility grounds, General Electric has contributed \$160 million to employee and community philanthropy programs and committed billions of dollars to develop eco-friendly products (Cheng et al. 2013). Intel has contributed $\$ 100$ million to energy conservation and global education programs (Hong et al. 2012).

For-profit, as well as not-for-profit organizations, are showing interest in environmental management and social sustainability. According to a KPMG (2013) survey, 93\% of Fortune Global 250 firms revealed their CSR in either a standalone report or a report integrated within the annual financial report (El Ghoul et al. 2016). Building on the CSR integration trend, Sroufe (2018) posits a theory of integrated management, saying firms managing environmental, social, and governance (ESG) performance across business functions will perform better than those not involved in CSR and ESG management. In another study, Sun and Cui (2014) explain that $90 \%$ of Fortune 500 companies are more transparent about CSR activities. For example, in the United States, one out of every nine professionally managed assets is invested in these companies with better CSR rankings valued at nearly $\$ 3$ trillion. In addition, leading organizations (see, for example, Bloomberg, MSCI, SASB, GRI, CPD, among others) evaluate the corporate performance along hundreds of ESG performance metrics.

A considerable amount of literature is available regarding CSR in the corporate finance domain (see, for example, Attig et al. 2013; Herremans et al. 1993; Long et al. 2019). These studies highlight the importance of CSR strategies to enhance firm financial performance. We build on these studies while exploring and providing new insights based on a synthesis of contemporary empirical work in the field. First, we define and contextualize the notion of CSR from a proponents' view of doing good for business versus an opponent's view 
of this paradigm. Our review of seminal work in the field over the past two decades explores the CSR and finance literature while finding three distinct areas of corporate finance: information environment, firm risk, and financing sources that are valuable to practitioners and scholars. Second, we discuss the critical literature in these areas and highlight a new and vital gap for future research.

\section{Proponents and Opponents of CSR}

The literature provides several theoretical frameworks for examining firms' ethical responsibility (like CSR). Carroll (1979), considered a pioneer in the CSR domain, outlines a three-dimensional corporate social performance (CSP) conceptual framework. The three dimensions are (1) the elements of CSR, (2) the social issues the organization must address, and (3) the organization's philosophy or mode of social responsiveness. In another study, McWilliams and Siegel (2001) state that the CSP model has a great deal in common with the stakeholders' perspective and is widely used in theoretical contexts.

Proponents of CSR find positive relationships between CSP and firm financial performance (Brine et al. 2007; Waddock and Graves 1997; Wu and Shen 2013). Most studies show that a firm's responsible behavior increases firm value. If CSR expenditures are made to better society and the environment, the firm value will increase because "doing good is good for business" (Adhikari 2016; Elfenbein et al. 2012; Servaes and Tamayo 2013). Prior evidence shows that CSR performance reduces competition shocks (Brine et al. 2007) and improves firm performance (Wu and Shen 2013). In a recent study, Lins et al. (2017) stressed that ethically and socially responsible firms experienced better financial performance and accelerated growth, enhanced labor productivity, and better access to finance. Overall, these studies demonstrated that a firm's ethical and social values are in the shareholders' and stakeholders' interest.

The corporate finance body of literature provides some mixed empirical results on CSR engagement. Opponents of CSR have challenged this "doing good is good for business" perspective supporting an agency perspective. Friedman's (2007) theory (this theory was first time presented by Friedman famous 1970 article in the New York Times) states that CSR engagements cause agency problems or conflicts of interest between managers and shareholders. Wright and Ferris (1997) empirically test this theory with South African data and find that stock prices reacted negatively to asset divestment announcements. Studies also show that CSR can reinforce agency problems (Adhikari 2016; Bénabou and Tirole 2010; Bhandari and Javakhadze 2017). Hemingway and Maclagan (2004) find that top management can also promote CSR to hide misbehavior. Some have even found that charitable giving goes indirectly to the CEO due to CEO-affiliated charities (Masulis and Reza 2015). More recent studies, Di Giuli and Kostovetsky (2014) find that directors' and employees' political leanings significantly affect CSR, ultimately hurting firm financial performance. Collectively, these prior studies indicate that managerial strategies under non-economic pressure create agency problems while opposing CSR efforts aligned with global agendas and country-level plans for increasing sustainable development.

Following the proponent's view, scholars have shown that if a firm constructs a CSR strategy on environmental and social grounds, the firm can take advantage of the "doing good is good for business" approach to business and financial management.

The framework provided in Figure 1 posits how these two opposing views redirect the outcomes of firm CSR policies. The basis of our framework is built on the theoretical underpinnings of prior business management work (see, for example, Flammer et al. 2019; Jones et al. 2019; Ting 2020; among others). The first theory (doing good is good for business) supports a firm's social and environmental efforts leading to better performance (Adhikari 2016; Lins et al. 2017; among others). Socially responsible firms improve the information flow to the investor, mitigating the firm's default risk and promoting a trusting culture among suppliers and buyers by increasing the overall trade credit. The second theory (agency theory) (Shapiro 2005) opposes this positive assertion and stresses that top management uses CSR to hide their misconduct (Shafai et al. 2018). These assertions 
have helped address how CSR affects default risk, the relationships between buyers and suppliers, and the information environment providing the context for this study.

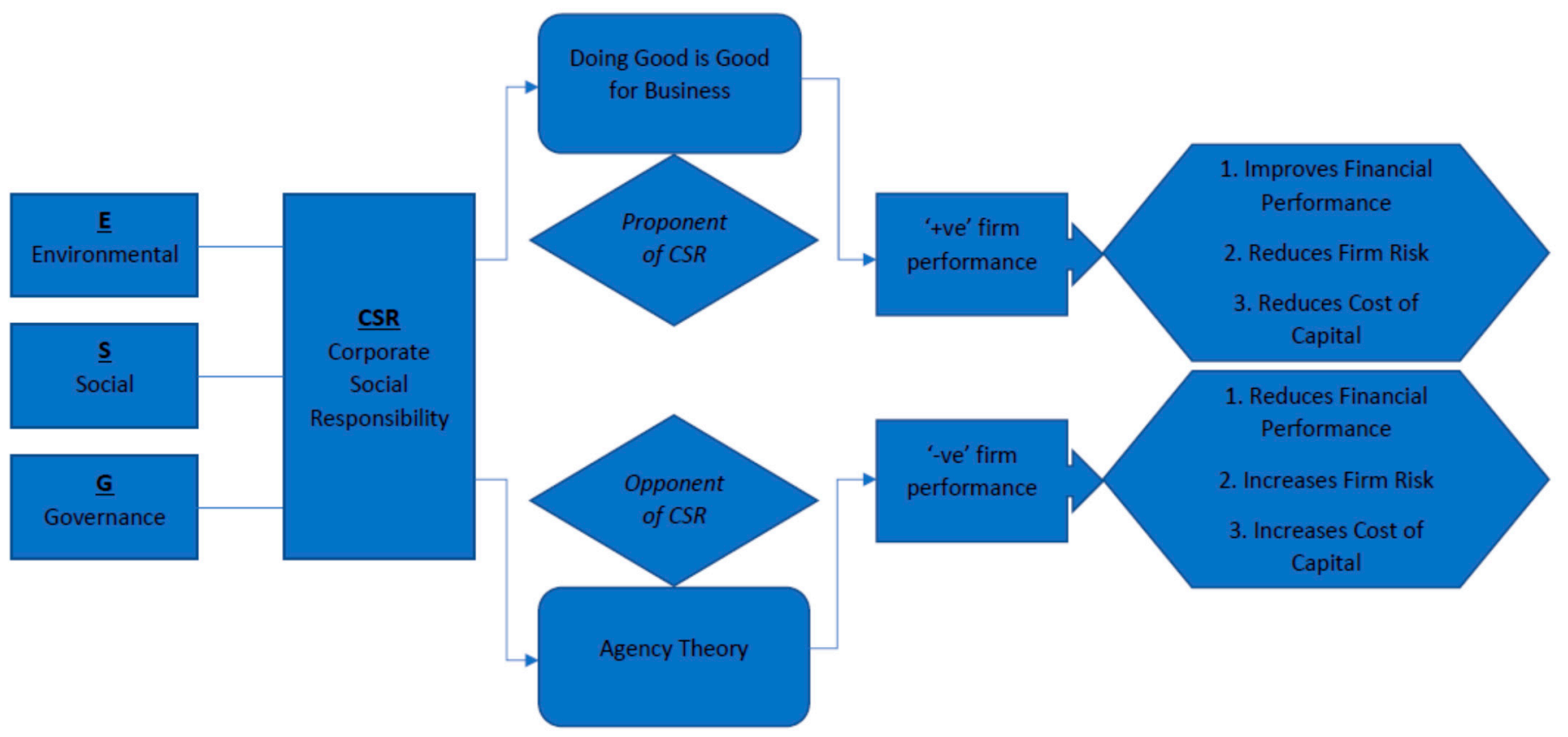

Figure 1. Conceptual Framework.

\section{Methods}

Next, we review the burgeoning studies in the business literature that show how a firm's standards involving CSR affect different firm financial attributes. These studies highlight the importance of investment in CSR activities and how voluntary CSR disclosures generate financial benefits for the firms. Further, we extend our discussion on three main areas (information environment, firm risk, and financing) in the corporate finance domain. Our motivation is to highlight the relationships between a firm's environmental and social practices; and other firm financial attributes in this analysis.

In the last two decades, business management and CSR have gained visibility (Harris et al. 2009; Harjoto and Rossi 2019) because of the growing amount of scholarly publications (Calabretta et al. 2011). We build upon previous research and review seminal studies that link the firm's CSR with firm information environment, firm risk, and financing sourcing. We mainly focus on the last 20 years (2000-2019) utilizing peer-reviewed publications in top-ranked journals of business management and corporate finance domains. These publications provide insight into current trends and empirical validation of relationships relevant to this study. We searched the literature using combinations of keywords: CSR, financial performance, information environment, firm risk, and financing.

For this study, we used Google Scholar to search these keywords and then downloaded the most relevant papers from their original databases (Sciencedirect, Willey, Springer, along with Taylor \& Fances, and Sage). A significant portion of our literature comes from financial management journals, such as Journals of Banking \& Finance, Journal of Corporate Finance, Management Science, and Journal of Finance. Next, we review these studies and synthesize findings while revealing new insights. After reviewing this literature, we take a step back from prior publications to also look at what leading multinational companies (MNCs) are doing regarding their CSR and environmental management efforts. Additionally, we also try to look at a country-level CSR context to see if it can provide additional layers of insight regarding the major themes from the literature and $\mathrm{MNC}$ practices. 


\section{CSR and Firm's Financial Characteristics}

Prior CSR literature review studies have used meta-analysis, and bibliometric analysis (Dreesbach-Bundy and Scheck 2017; Malik 2015; Vishwanathan et al. 2020; among others). To identify CSR potential studies as part of our literature sample, we use only those articles that we could find using several primary keywords and deemed the most relevant to this study resulting in 26 prior studies. A significant body of literature on business management has investigated CSR's links with firm financial performance. Table 1 contains the summary information with the authors, title, hypothesis, data, methodologies, and findings of all the papers discussed in this study.

There are two widely cited meta-analyses on the relationship of CSR with firm performance. In the first, Margolis and Walsh (2003) analyze the literature from 1972 to 2002 and report that, of 127 studies, 54 show a positive relationship between CSR and firm performance. In the second analysis, Margolis et al. (2009) investigate 214 studies and conclude that, overall, CSR has a positive impact on firm performance but less so in the last decade. To increase CSR levels, organizations spend more on CSR activities, but investors are unwilling to pay a CSR premium (Pava and Krausz 1996). Overall, these meta-analyses show that investment in CSR activities improves firm financial performance.

As was found in previous studies, CSR improves a firm's financial performance. CSR also reduces financial risk (Herremans et al. 1993). Investors want to earn maximum stock returns for a given level of firm risk. In a recent article, Kim et al. (2014) found that an organization's strong social ethics mitigate its stock price crash risk. Socially and ethically responsible firms maintain a high level of transparency and engage less in bad news hoarding, which leads to lower crash risk. In addition, CSR has a negative association with idiosyncratic risk (Lee and Faff 2009). Mishra and Modi (2013) investigate the differential impacts of positive and negative CSR on idiosyncratic risk. Positive CSR reduces risk, but this is not guaranteed, while negative CSR increases risk. A similar study finds that high media coverage of a firm's corporate social irresponsibility increases its financial risk (Kölbel et al. 2017). The study reviewed 539 firms domiciled in 38 countries. The authors looked at every quarter of the firms between 2008 to 2013 in an unbalanced panel of 9939 firm-quarter observations.

The corporate finance literature provides evidence about the link between CSR and other firm financial attributes but overlooks these relationships' broader implications. Under certain circumstances (e.g., reduction in future cash flows), CSR expenditures create value for shareholders (Fatemi et al. 2015). Better CSR performance helps organizations obtain loans with easy terms and conditions and is also helpful when an organization has no collateral (Goss and Roberts 2011). Cai et al. (2016) use the MSCI ESG Intangible Value Assessment (IVA) database. Their final sample consists of 2636 firm-year observations from 2001 to 2006 from 36 countries. They find that minor variations in CSP ratings are due to firm characteristics. Interestingly they also find that a significant proportion of CSP rating changes are due to country-level factors such as institutional, cultural, and economic development.

In the business literature, the two most common ESG ratings are the MSCI ESG Ratings and Asset4, (Asset4 ESG ratings consist of ESG factors), which consist of different CSR dimensions (Cooper et al. 2010; Humphrey et al. 2012; Krüger 2015; Lys et al. 2015). The MSCI ESG ratings were formerly known as the KLD ratings. These ratings consist of seven qualitative issues: community, diversity, employee relations, the environment, humanity, product, and corporate governance. These CSR dimensions also have differential associations with firm financial characteristics. Bouslah et al. (2013) find that community strength has a negative impact, and diversity positively affects firm risk. The authors also see that employee, diversity, and corporate governance concerns positively associate with firm risk for Standard \& Poor's (S\&P) 500 companies. The literature also provides evidence that some, but not all, CSR dimensions are associated with firm financial attributes (Attig et al. 2013; Cai et al. 2015; El Ghoul et al. 2011). Attig et al. (2013) find that the five 
dimensions of community, diversity, employee relations, the environment, and product quality/safety are associated with credit ratings, but not the human rights dimension.

Our review of this literature in this study aims to discuss the relevant findings from prior studies that link CSR with various firm financial attributes and highlight gaps for further research in the business CSR domain. To achieve this objective, we next explore the literature on CSR and corporate finance. In subsections, we discuss the prominent studies in CSR within three main areas of corporate finance. Details regarding the CSR articles can be found in Table 1.

Table 1. Referenced Literature in CSR.

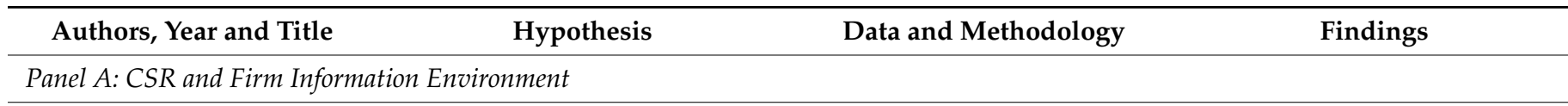

1. Positive CSR information will be associated with a greater intention to consume a company's product compared to negative CSR information.

Alniacik et al. (2011)

How Corporate Social Responsibility Information Influences Stakeholders' Intentions
2. Positive CSR information will be associated with a greater intention to seek employment with a company compared to negative CSR information. 3. Positive CSR information will be associated with a greater intention to invest in a company compared to negative CSR information.
In this study, they use the response of 250

undergraduate students from two Turkish universities.

University students are potential customers and active users and future investors and employees of consumer electronics.
Their findings show that firm positive CSR information enhances consumer intentions to purchase products from, potential employees' intentions to seek employment with, and potential investors' intentions to invest in the company.
Gamerschlag et al. (2011) Determinants of voluntary CSR disclosure: empirical evidence from Germany
1. CSR is positively associated with company visibility. 2. CSR is positively associated with company profitability. 3. CSR is positively associated with more dispersed ownership.
They used 520 firm-year observations from 2005 and 2008 using the Global Reporting Initiative (GRI). They focus on the German DAX, MDAX, and SDAX.
They find that CSR disclosures are affected by their visibility, shareholder structure, and relationship with U.S. stakeholders. More environmental disclosure leads to a firm's higher profitability.

In this study, the sample consists of 233 firm-year using data from the Association for Investment Management and Research (AIMR) ranking for the years 1989 to 1992 of all non-banking firms.

Their final sample consists of 2084 firm-year observations covering the years 1982 to 1995. They only use those companies whose disclosure data are available on AIMR's database.
Their results show that socially responsible companies are more willing to provide financial disclosures. This relation is strengthening through better investor relations practices.

They find that overall firm disclosure policy improves the information in stock prices. They make this estimation using analyst evaluation of firm disclosure policy. 
Table 1. Cont

\begin{tabular}{llll}
\hline \multicolumn{1}{c}{ Authors, Year and Title } & \multicolumn{1}{c}{ Hypothesis } & Data and Methodology & \multicolumn{1}{c}{ Findings } \\
& & & $\begin{array}{l}\text { Socially responsible } \\
\text { companies are less likely to } \\
\text { manage their earnings }\end{array}$ \\
Kim et al. (2012) & $\begin{array}{l}\text { 1: Socially responsible } \\
\text { companies are less likely to } \\
\text { Is Earnings Quality }\end{array}$ & $\begin{array}{l}\text { The sample consists of 18,160 } \\
\text { firm-years observations from }\end{array}$ & through discretionary \\
Associated with Corporate & engage in earnings & 1991 to 2009 using the DSI400 & accruals, manipulate real \\
Social Responsibility? & management. & index as a CSR indicator. & $\begin{array}{l}\text { operating activities, and be } \\
\text { the subject of the SEC } \\
\end{array}$ \\
& & & investigation. \\
\hline
\end{tabular}

They find an inverse relationship between the value of both upgrade and

1. CSR-related information is associated with the variation in the value of analysts' recommendation revisions. 2. Changes in CSR-related information levels are associated with the value of analysts' recommendation revisions.
They used MSCI ESG data and IBES from 1995 to 2011 for U.S. companies. The final sample consists of 11,828 firm-year observations. downgrade revisions and the supply of CSR-related information compiled by third-party institutions, suggesting that CSR-related data are associated with a richer information environment that makes it more challenging for analysts to issue informative recommendations, thereby mitigating their contribution to the price discovery process.

Results show that conservative companies, with a high level of accruals quality and those that carry out earnings management practices to a lesser extent, report high-quality financial information and, moreover, high-quality CSR information.

(2015)

Effect of Financial Reporting

Quality on Sustainability

Information Disclosure
Sustainable information standardized disclosures have a negative (substitutive) relationship with financial reporting quality.
Their sample comprises 747 international listed nonfinancial companies from 25 countries from 2002 to 2010 using the Tobit method for panel data.
1. Voluntary CSR disclosures increase information availability by reducing the asymmetric information problem. 2. Voluntary CSR disclosures reduce the information available due to more stakeholder-oriented environments.
They produce their results using the GMM estimator for an international sample of 575 firms for the period 2003 to 2009.
Greater asymmetric information leads to higher voluntary information disclosure practices, reducing the agency problem in environments characterized by strong socially responsible commitment.

\section{They report that CSR} disclosures on websites are influenced by both industry and country. Thus, corporations are increasingly concerned with communicating ethically and responsibly their stakeholder diversity through the web. 
Table 1. Cont.

\begin{tabular}{|c|c|c|c|}
\hline Authors, Year and Title & Hypothesis & Data and Methodology & Findings \\
\hline \multicolumn{4}{|l|}{ Panel B: CSR and Firm Risk } \\
\hline $\begin{array}{l}\text { Attig et al. (2013) } \\
\text { Corporate Social } \\
\text { Responsibility and Credit } \\
\text { Ratings }\end{array}$ & $\begin{array}{l}\text { 1. CSR reduces the perceived } \\
\text { risk of financial distress, and } \\
\text { that has a positive impact on } \\
\text { firm credit ratings. }\end{array}$ & $\begin{array}{l}\text { They used an unbalanced } \\
\text { panel of 11,662 firm years' } \\
\text { observations representing } \\
1585 \text { unique U.S. firms over } \\
\text { the period 1991-2010 using } \\
\text { MSCI ESG and CSRSP, and } \\
\text { order Probit model. }\end{array}$ & $\begin{array}{l}\text { Using the U.S. sample, they } \\
\text { conclude that socially } \\
\text { responsible companies enjoy a } \\
\text { relatively high credit rating. } \\
\text { Furthermore, they explore } \\
\text { that both strength and } \\
\text { concerns influence the credit } \\
\text { rating. }\end{array}$ \\
\hline $\begin{array}{l}\text { Chollet and Sandwidi (2018) } \\
\text { CSR engagement and } \\
\text { financial risk: A virtuous } \\
\text { circle? International } \\
\text { evidence }\end{array}$ & $\begin{array}{l}\text { 1. CSR engagement lowers } \\
\text { financial risk. } \\
\text { 2. Social and governance } \\
\text { commitment reduces financial } \\
\text { risk. }\end{array}$ & $\begin{array}{l}\text { They used Asset } 4 \text { data as a } \\
\text { CSR measure and systematic, } \\
\text { firm-specific, and total risks } \\
\text { for the financial risk measure. } \\
\text { The final sample consists of } \\
23,194 \text { firm-year observations } \\
\text { from } 2003 \text { to } 2012 \text { from } 62 \\
\text { countries. }\end{array}$ & $\begin{array}{l}\text { They show that a firm's good } \\
\text { social and governance } \\
\text { performance lowers its } \\
\text { financial risk, thereby } \\
\text { reinforcing its commitment to } \\
\text { good governance and } \\
\text { environmental practices. }\end{array}$ \\
\hline
\end{tabular}

Cui et al. (2017)

Corporate Social

Responsibility, Religion, and

Firm Risk
1. CSR negative association with firm risk is more pronounced if H.Q. (headquarter) in a religious area.
They used KLD data as a CSR measure and CompStat for the financial risk measure. The final sample consists of 27,800 firm-year observations from 1991 to 2013 from U.S.

They used Asset4 ESG data as a CSR measure. The final sample consists of 1349 firm-year observations from 2007 to 2017 from 18 European countries.

They used KLD and monthly Fama French portfolio data from June 1992 to July 2006. They find results by using the Fama-Macbeth and GMM models.

CSR has a significant influence on stock returns.
1. Better CSR ratings lead to lower CDS spreads. higher CDS spreads. responsible investment

\section{Galema et al. (2008)}

The stocks at stake: Return and risk in socially
Hypothesis: He develops the notion of corporate social responsibility as a real option and its implications for risk management.
Husted (2005)

Risk Management, Real Options, and Corporate Social Responsibility
They find that CSR religiosity is negatively associated with firm risk.
Final results support that a better CSR rating brings a significant decrease in CDS spreads.
They find that diversity, environment and product strategies dimensions of CSR has a significant positive impact on stock returns.
Real options theory suggests that corporate social responsibility should be negatively related to the firm's ex-ante downside business risk.

With controversial industries (such as alcohol, tobacco, gambling, and others) sample, they find that improved CSR performance is helpful to reduce the firm risk. Furthermore, they explore that CSR decreases the firm risk statistically more significantly with controversial industry firms than in noncontroversial industry firms. 
Table 1. Cont

\begin{tabular}{|c|c|c|c|}
\hline Authors, Year and Title & Hypothesis & Data and Methodology & Findings \\
\hline $\begin{array}{l}\text { Kim et al. (2014) } \\
\text { Corporate social } \\
\text { responsibility and stock } \\
\text { price crash risk }\end{array}$ & $\begin{array}{l}\text { 1. CSR has a significant } \\
\text { influence on firm-level stock } \\
\text { price crash risk. }\end{array}$ & $\begin{array}{l}\text { They used 12,978 firm-year } \\
\text { observations from } 1995 \text { to } \\
2009 \text { using the MSCI ESG } \\
\text { database. They use a cluster } \\
\text { effect at both firm and year } \\
\text { levels. }\end{array}$ & $\begin{array}{l}\text { They find that CSR } \\
\text { performance is negatively } \\
\text { associated with future crash } \\
\text { risk after controlling the crash } \\
\text { risk determinants. Because } \\
\text { socially responsible } \\
\text { companies have a high level } \\
\text { of transparency and low level } \\
\text { of bad news hoarding. }\end{array}$ \\
\hline $\begin{array}{l}\text { Lee and Faff (2009) } \\
\text { Corporate Sustainability } \\
\text { Performance and } \\
\text { Idiosyncratic Risk: A Global } \\
\text { Perspective }\end{array}$ & $\begin{array}{l}\text { 1. Corporate social performance } \\
\text { has a significant association } \\
\text { with firm idiosyncratic risk. }\end{array}$ & $\begin{array}{l}\text { They used the DJSI and DJGI } \\
\text { index from } 1998 \text { to } 2002 \text { with a } \\
\text { combined sample of } 11,479 \\
\text { firm-year observations. }\end{array}$ & $\begin{array}{l}\text { Their findings show that } \\
\text { leading (lagging) corporate } \\
\text { social performance (CSP) } \\
\text { firms exhibit significantly } \\
\text { lower (higher) idiosyncratic } \\
\text { risk and that idiosyncratic risk } \\
\text { might be priced by the } \\
\text { broader global equity market. }\end{array}$ \\
\hline
\end{tabular}

1. CSR has a negative relationship with firm default risk.

Sun and Cui (2014) Linking corporate social responsibility to the firm default risk
2. When a capability is higher, CSR has a strong impact on reducing default risk.

3. When environmental dynamism is higher, CSR has a strong impact on reducing default risk.
The final sample consists of 829 observations from 303 firms for 2008 to 2010 period. They use standard and poor credit rating data as a

financial default risk measure.
They conclude that CSR has a strong effect on firm financial default risk reduction.

Moreover, they observe that this relationship is stronger for high dynamism environments than low dynamism environments.
Cheng et al. (2014)

Corporate Social

Responsibility and Access to Finance
1. CSR performance reduces agency cost due to effective stakeholder engagement.

2. CSR performance reduces the information asymmetry due to extensive CSR disclosures.
They used Asset4 data as a CSR measure and Kaplan-Zingales Index for the capital constraint measure. The final sample consists of 10,078 firm-year observations from 2002 to 2009 from 49 countries.
They find that better CSR performance faces significantly lower capital constraints. Stakeholder engagement and transparency both play an essential role in creating this impact. These results are also consistent with both the social and environmental dimensions of CSR.

They find a positive relationship between CSR stands-alone CSR reports issuance and a higher level of analyst forecast opacity. Furthermore, they explore that this association is more pronounced with more stakeholder-oriented countries and firms with a high level of financial disclosures. 
Table 1. Cont.

\begin{tabular}{|c|c|c|c|}
\hline Authors, Year and Title & Hypothesis & Data and Methodology & Findings \\
\hline $\begin{array}{l}\text { El Ghoul et al. ( } 2011) \\
\text { Does corporate social } \\
\text { responsibility affect the cost } \\
\text { of capital? }\end{array}$ & $\begin{array}{l}\text { 1. High CSR firms have a lower } \\
\text { cost of equity. }\end{array}$ & $\begin{array}{l}\text { They used KLD STATS data } \\
\text { for CSR measure. Their final } \\
\text { sample consists of } 12,915 \\
\text { observations representing } \\
2809 \text { unique firms between } \\
1992 \text { and } 2007 . \text { To test their } \\
\text { hypothesis, they use a pooled } \\
\text { cross-sectional time series } \\
\text { regression. }\end{array}$ & $\begin{array}{l}\text { They find that firms with } \\
\text { better CSR performance } \\
\text { exhibit cheaper equity } \\
\text { financing. They also suggest } \\
\text { that employee relations, } \\
\text { environmental policies, and } \\
\text { product strategies dimensions } \\
\text { of CSR are playing an } \\
\text { essential role in reducing the } \\
\text { cost of equity. }\end{array}$ \\
\hline
\end{tabular}

1. Improved CSR has a significant influence on the firm's cost of equity capital.

Feng et al. (2015)

Equity Financing and Social

Responsibility: Further

International Evidence

2. CSR's negative relationship with the cost of equity capital is well-established in North America and Europe compared to other regions.
In this study, they used 10,803 firm-year observations from 2002 to 2010. They use Thomson Reuters Asset4 data from 25 countries.

1. CSR concerns have a negative association with loan maturity. 2. CSR strength has a positive association with loan maturity (mitigating risk view).
They used the KLD dataset of 3996 loans extended to 1265 firms from 1991 to 2006.
They find that better CSR performance reduces the cost of equity capital in North America and Europe. But these results do not hold for Asian countries.
Goss and Roberts (2011) social responsibility on the cost of bank loans
Hypothesis: Increase in social responsibility increases the firm credit rating
Used the KLD database for CSR measurement. Their final sample consists of 2516 firm-year observations from 1995 to 2007.
They provide evidence in support of CSR concerns pay between 7 and 18 basis points more than firms that are more responsible. Lenders give importance to CSR strengths in the absence of security.

They find that more socially responsible companies enjoy a more favorable credit rating. One standard deviation increase in CSR measure increase the $4.5 \%$ of firm credit rating. Furthermore, they also test these results using geographic proximity with 2SLS.

The results confirm that a firm with a leading record of employee well-being significantly reduces the probability of bankruptcy through a lower debt ratio. After controlling the differences in leverage, they observe that with better employee well track records firm improves their credit rating.

\subsection{CSR and the Firm's Information Environment}

CSR has a substantial impact on a firm's information environment. As previously discussed, $90 \%$ of Fortune 500 companies are transparent and publicly report their CSR efforts. Martínez-Ferrero et al. (2015) demonstrate that conservative companies with lesser earnings management practices and high levels of accrual quality report high-quality CSR information and high-quality financial information. Martínez-Ferrero et al. (2016) 
examine the impact of CSR disclosure on information asymmetry. They find that voluntary disclosures regarding CSR reduce the information asymmetry problem. More significant information asymmetry leads to high levels of voluntary information disclosures; these disclosures reduce agency problems in a high socially responsible environment.

Organizations make their environment more informative with the help of extensive CSR disclosures. Wanderley et al. (2008) use a mix of qualitative and quantitative approaches to demonstrate this argument after analyzing 127 corporations' websites; they conclude that both the country and the industry significantly influence CSR disclosures on electronic media. These corporations belong to the G20 countries, along with Brazil, Chile, China, India, Indonesia, Mexico, South Africa, and Thailand. Alniacik et al. (2011) show the importance of the CSR information environment. The data were collected from 250 undergraduate students studying in various departments of two Turkish universities participating in the study as part of their classroom activities. They explore the link between positive and negative CSR performance and investment, purchases, and employment intentions. Generally, positive CSR is associated with strong social and environmental performance and negative CSR with weak social and environmental performance. According to Alniacik et al. (2011), positive CSR enhances potential consumer purchase intentions, potential investor investment intentions, and potential employee's employment intentions.

The business management literature provides growing amounts of evidence on CSR's impact on a firm's overall disclosure policy. Gamerschlag et al. (2011) explore the determinants of voluntary CSR disclosures in the German context. Consistent with political cost theory, their results show that German companies' shareholder structure, visibility, and U.S. stakeholder relationships affect German companies' CSR disclosure issues. Gelb and Strawser (2001) find a positive association between CSR and firm financial disclosures. More socially responsible companies provide information with extensive financial disclosures in comparison to less CSR-focused firms. Stakeholders recognize such information disclosure, which increases their satisfaction.

Numerous studies have investigated the relationship between CSR and financial information. Using the Domini Social Index 400 (DSI 400) as a CSR indicator, Kim et al. (2012) address this issue and find that socially responsible companies are less involved in manipulating operating activities and managing earnings through discretionary accruals. The authors also suggest that ethical concerns drive managers to produce high-quality financial reports. In the same vein, Dhaliwal et al. (2012) note that CSR standalone reports play an essential role in complementing financial disclosures. This relationship is more robust for firms and countries with high-quality financial disclosures. Furthermore, the authors show that financial and CSR disclosures act as a substitute to reduce equity costs.

The above-discussed studies help us understand that an organization's financial information environment has dynamic relationships with its CSR practices (Lee et al. 2018). According to Haggard et al. (2008), an influential firm disclosure policy increases the level of firm-specific information in stock returns. Therefore, a more significant amount of information is impounded in the stock prices of the company. Stock prices are thus also a source of firm-specific information for investors, analysts, and stakeholders. Here we see opportunities to advance the field with a focus on growing amounts of information and transparency. The corporate finance literature is paying more attention to the relationships between CSR and reporting as trends show transparency in reporting CSR and earnings management practices increasing over time.

\subsection{CSR and Firm Risk}

In the corporate finance literature, firm CSR increases firm valuation and decreases firm risk. Following real options theory, Husted (2005) concludes that CSR has a negative relationship with firms' ex-ante downside risk. The author also determines that the riskfree interest rate, the exercise price, uncertainty, and time play a vital role in the valuation of CSR investments. Some industries are controversial (e.g., alcohol, tobacco, firearms) in investors' eyes, and socially responsible investors hesitate to invest in these types of 
industry stocks. Jo and $\mathrm{Na}$ (2012) argue that CSR engagement inversely affects firm risk in controversial industries, with a more substantial effect in more controversial industries than in noncontroversial industries. In light of their study, we can say that top management's engagement in CSR activities for those enterprises within controversial businesses sectors improves their risk management efforts.

Most business finance researchers use well-known risk measures (e.g., stock return beta and the standard deviation of returns) as a risk proxy. Galema et al. (2008) report that socially responsible investments impact stock returns by lowering the book-to-market ratio and not generating positive alphas. The book to market is used as a proxy for firm risk. Furthermore, the authors explain that this relationship strengthens CSR's diversity, product quality/safety, and environmental dimensions. Their research also supports our argument that not all CSR dimensions or factors affect firm characteristics in the same way. Particular measures of risk are also associated with stock prices (e.g., stock price crash risk). Kim et al. (2014) find that firm social responsibility performance is negatively related to stock price crash risk, which occurs in socially responsible firms due to high moral values and ethical standards (less bad news hoarding and a high level of transparency).

Using data from 2003 to 2012, Chollet and Sandwidi (2018) show that a better CSR reputation generates better stock returns at lower risk levels. They attribute such CSR investment performance to the psychic utility of economic gains. This work stresses that social and governance performance effectively mitigates financial risk after using international data from 67 countries. In light of the global evidence, Lee and Faff (2009) find that a firm's CSR performance leadership significantly mitigates its idiosyncratic risk. The authors analyze idiosyncratic risk and its determinants and find that it substantially reduces the apparent difference between lagging and leading CSR portfolios.

Credit agencies can consider a firm's socially responsible reputation as collateral (Drago et al. 2019). In a recent study, Sun and Cui (2014) use S\&P credit rating (a firm's credit rating is the firm's ability to fulfill its financial commitment (or meet the expectations of debtholders) scores as a proxy for default risk and find an increase in CSR level reduces firm default risk. Several papers have examined the association between CSR and firm credit ratings. Attig et al. (2013) conclude that credit rating agencies give higher ratings to firms with better CSR performance. Furthermore, they find that community relations, diversity, employee well-being, the environment, and product strategies play an essential role in increasing creditworthiness. In the same vein, Jiraporn et al. (2014) inspect the association between CSR and credit rating from a geographical perspective. Their findings also support the previous literature. Improved credit ratings are associated with a lower likelihood of firm default risk. Along with the literature, we conclude that CSR increases credit ratings and reduces firm default risk.

Most of the evidence presented in this firm risk domain shows a negative association between CSR and different firm risk measures (e.g., idiosyncratic risk, stock price crash risk, default risk). Using data from 34 countries, Altman et al. (2016) state that the financial distress prediction accuracy (75\%) of the Z-score model (Altman 1968) is reasonably good compared to the market-based model and can be further improved (to $90 \%$ ) by using country-specific variables. However, the association between CSR and firm FDR (financial distress risk) (accounting-based measures, i.e., accounting-based measures of FDR are the Z-score, O-score, and ZM-score models) is still in question in the corporate finance literature, and this provides opportunities for future research to help provide more clarity as to the strength and direction of these relationships.

\subsection{CSR and Financing Sources}

Firms need better access to financing to run organizational activities smoothly. Most commonly, firms obtain financing from their shareholders and through bank loans. Publicly listed firms can obtain financing from the capital and credit markets. Acquiring investments from the credit market can be advantageous for firms because of tax benefits and the non-dilution of ownership. Firms' positive behavior toward the community and 
the environment also plays an incremental role in their access to financing at cheaper rates. Cheng et al. (2014) find that firms reduce capital constraints with improved CSR performance. The authors use the Kaplan and Zingales (1997) index to measure capital constraint and show that both environmental and social dimensions drive this relationship.

CSR not only improves access to financing but also reduces the overall cost of capital (El Ghoul et al. 2011), minimizing both its components, that is, the cost of equity and the cost of debt. Feng et al. (2015) state that better CSR performance minimizes the cost of equity. They used a global sample and concluded that good CSR performance reduces the cost of equity in North America and Europe but find this association does not exist in Asian countries. This is based on 10,803 firm-year observations from 25 countries from 2002 to 2010. Dhaliwal et al. (2014) also find a negative association between CSR and the cost of equity, with a more pronounced association in stakeholder-oriented countries. On the other hand, better CSR performance also reduces bank loans' cost (Goss and Roberts 2011).

Additionally, CSR is essential to obtain debt financing at lower rates through improved credit ratings. Jiraporn et al. (2014) state that better CSR performance enhances a firm's credit rating potentially because of social interactions, local competition, or investor clienteles. Firms' CSR policies are affected by the firms' geographic peers' (by three-digit zip codes) and industry peers' CSR policies They conclude that funding agencies and banks greatly value firms' ethical behavior toward society. Attig et al. (2013) similarly find that firms with good social performance enjoy high credit ratings. CSR is a combination of both CSR-supportive activities (strengths) and non-CSR-supportive activities (concerns). Attig et al. (2013) also show that CSR support positively impacts U.S. firm credit ratings and nonsupport activities have a negative effect. These recent studies highlight CSR's importance in presenting a good firm image through high credit ratings to lending institutions.

During the 2007-2008 financial crisis, several organizations defaulted because of the credit crunch. CSR plays a vital role in reducing a firm's financial default risk. Sun and Cui (2014) state that CSR performance helps firms mitigate financial default risk (a firm's measure of financial default risk is its S\&P credit rating) with a more pronounced association for firms in a highly dynamic environment. In support of this, Verwijmeren and Derwall (2010) find that firms can reduce bankruptcy probability through a leading track record in employee well-being. Hence, we conclude that a firm can mitigate default risk by opting for high moral and ethical values.

We have discussed the positive association between firm CSR performance and access to financing. Better access to funding at cheaper rates increases the financial soundness of high-CSR firms (García-Sánchez et al. 2019) and reduces their default risk (Cui et al. 2017). Firms with better CSR have lower costs of equity and debt compared to low-CSR firms. Trade credit is also a significant source of financing for organizations. Previous studies show CSR links with equity and debt financing. The association of CSR and financing sources is growing. We see CSR as growing in the future and note the importance of exploring relationships between CSR and trade credit as an area of research with the potential to uncover new relationships in a global marketplace.

\subsection{CSR MNCs and Country Characteristics}

In addition to our search and the synthesis of prior financial management literature, we also wanted to examine large multinational companies (MNCs) to look at their performance and country context for taking on CSR initiatives. We do this to help look for new insights and current practices. To provide scholarly and practical findings, we reviewed Fortune 500 companies' CSR performance. We selected the top 10 Fortune 500 companies in 2018 and examined their Asset4 environment, social, and governance (ESG) data over eight years (2011-2018). We chose these years due to the growing focus on CSR, the emergence of creating shared value (Kramer and Porter 2011), and this time is the third generation of CSR by Trapp (2012). Figure 2 shows all U.S. firms' average CSR performance compared to the top 10 Fortune 500 firms, with most Fortune 500 companies in the top quartile (75-100\%). 
The continuous line shows the average CSR scores of all U.S. companies. Each year's average score indicates that most U.S. companies are doing something for society, i.e., the community and the environment.

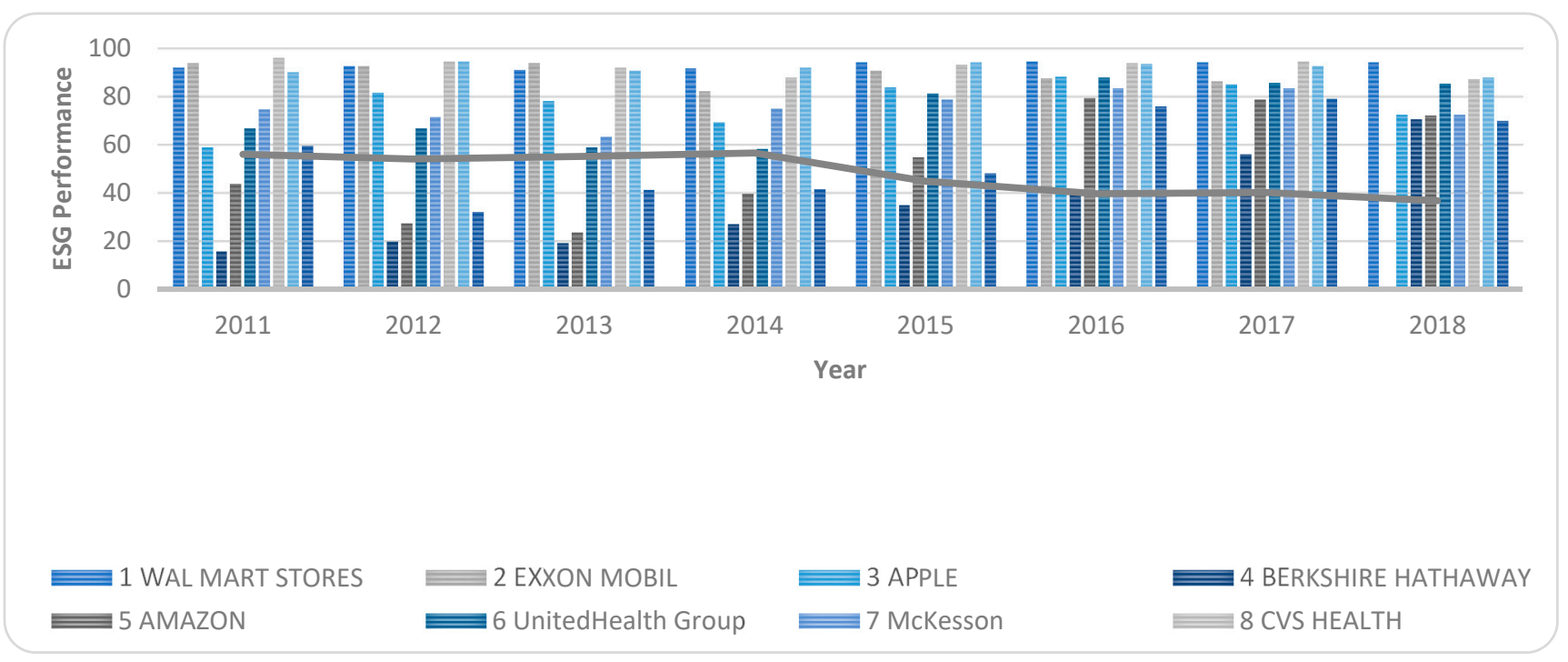

Figure 2. CSR performance of top ten Fortune 500 and average of U.S. companies from 2011 to 2018.

This figure shows the CSR performance of the top 10 Fortune 500 US and average U.S. companies. We use data from Asset4 ESG to measure CSR performance. Colored bars indicate the individual performance of the company, and the black line shows the average CSR performance of 1650 unique U.S. companies' year-wise. This figure depicts the CSR performance by country using data from Asset4 ESG in 2018. We excluded countries for which the total number of firms is below ten. Figure 3 shows the CSR performance of different countries, using Asset4 ESG data from 2018. The map shows European countries' (e.g., France, Spain, Netherland, Finland, Sweden) with high commitment to CSR. We exclude all countries with fewer than 10 firms in the Asset4 database in 2015. In 2018, Asset4 ranked large economies (e.g., the United States, China) below average on the social responsibility index.

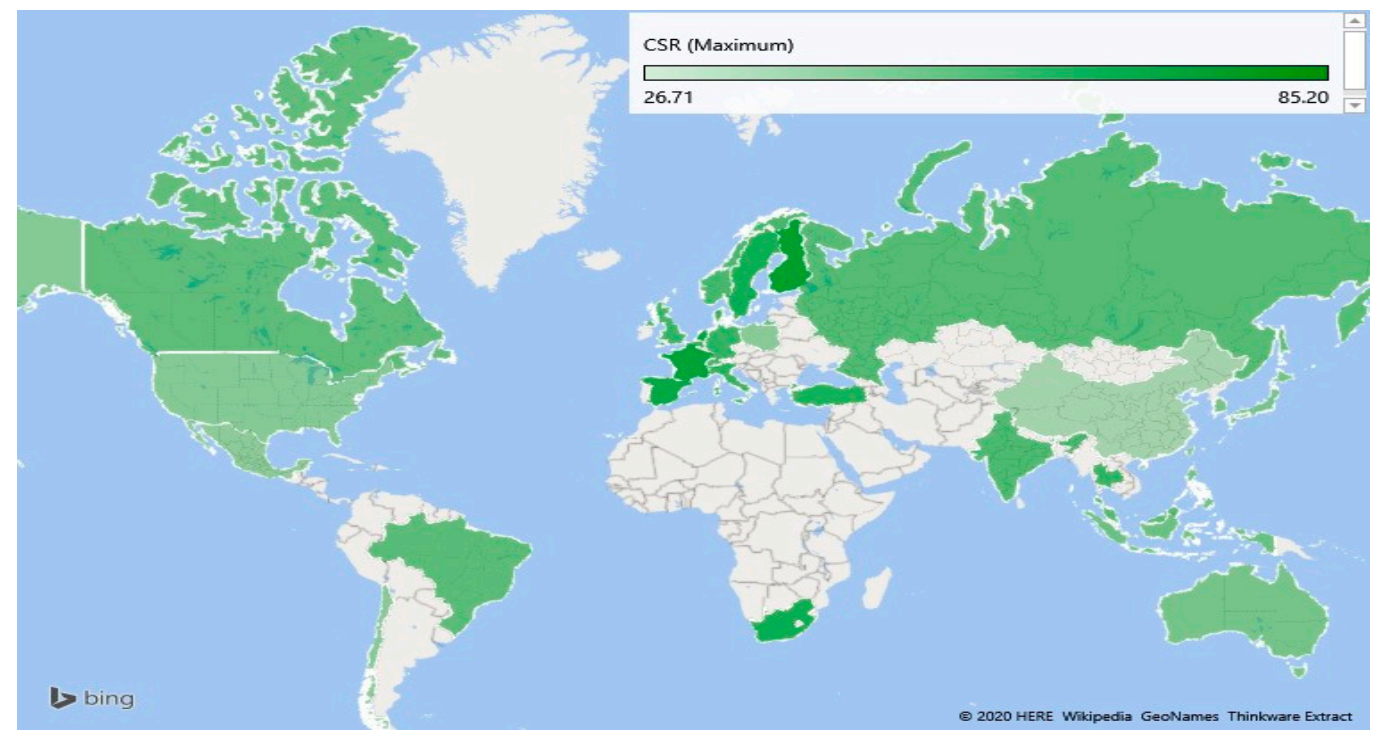

Figure 3. Global CSR performance. 


\section{Discussion}

Based on an extensive literature review of CSR, our synthesis of information shows that firm CSR performance affects firm financial performance, firm risk, the cost of capital, and financial disclosures. The evidence from the literature suggests there have been and will be positive impacts from CSR and environmental management. Our approach in this study was to approach the CSR paradigm through the lens of two competing theories: (1) doing good is good for business, and (2) CSR creates agency problems. Our findings may be counterintuitive to what many in the financial sector have been saying for years, i.e., CSR is bad for business. Business finance researchers mostly show us that CSR has a positive relationship with financial performance and a negative association with firm risk, improves a firm's information environment, and reduces the cost of capital. Based on these findings, we posit that, overall, CSR investment creates value for organizations and their stakeholders. In general, our findings, therefore, support the argument that doing good (socially and environmentally) is good for business.

In support of the above conclusion, a battery of literature finds that the firm's responsible strategies are an actual effort and ultimately improve the firm performance and overall image (Fatemi et al. 2015; Jiraporn et al. 2014; among others). Furthermore, we find that the CSR literature in the corporate finance domain supports this notion that a firm's social and environmental activities generate financial benefits for the organization. Our work collectively supports the positive aspects of the theoretical models suggesting "Doing Good is Good for Business" (Margolis and Walsh 2003; Margolis et al. 2009).

The second objective of our study was to identify new relations between CSR and corporate finance. First, we discuss the CSR impact on a firm's information environment. Many business finance researchers state that firms doing more CSR promote information symmetry through financial and nonfinancial disclosures (Dhaliwal et al. 2012; Gelb and Strawser 2001; Kim et al. 2012). On the other hand, we find that CSR's link to information impounded into stock prices is still in question. Second, we explore the literature on CSR and different measures of financial risk. We find that the link between CSR and FDR is still inconclusive. Third, we discuss the literature on CSR and firm access to financing. CSR has a positive relationship with equity financing (Feng et al. 2015) and access to bank loans (Cheng et al. 2014; Goss and Roberts 2011). The relationships between CSR and trade credit are still undefined, however. This study identifies the emerging trends and pathways for future research by shining new light on the business management and financial management frontier.

We extend knowledge by identifying the gaps in corporate finance in relation to CSR. In reference to the cited studies we review, we are able to highlight the three new CSR associations with price information, financial distress risk, and trade credit. Above mentioned gaps will open new doors in the firm's financial and CSR domains. Further, we also propose that findings are significantly different in developed and emerging economies due to their level of priorities (Jamali and Carroll 2017; Sardana et al. 2020).

In comparison to prior CSR literature review studies, our paper is unique and constructive (Dionisio and Vargas 2020; Malik 2015; Pope and Wæraas 2016). Malik (2015) proffers an understanding between CSR and firm value studies. In another paper, Pope and Wæraas (2016) stress another side of a firm's ethical initiatives focused on CSR-washing. This work uses data from three sources (e.g., Dissertations, Google Scholar, and the New York Times) to show the growing importance of CSR-washing in the business management domain. In a more recent study, Dionisio and Vargas (2020) selected 89 articles from top business management journals and performed a thematic analysis of the literature. Our study utilizes the relevant articles from the last 20 years to explore theoretical justification for CSR, and we engage this literature to identify potential gaps for future research. 


\section{Conclusions}

Our review of the CSR literature is not free of limitations. In this study, we focus on refereed journals' papers, working papers, and books and present our findings of the empirical evidence presented in the CSR literature. However, there could still be other studies unknown to us with different results or conclusions. Second, we have identified the gaps in these domains, but we do not define how researchers should find the answer to these questions. Third, this work only discusses the direct relationship (i.e., how CSR affects financial performance). Prior literature also shows the indirect relationships (for example, Galbreath (2018) argues that CSR mediates the gender diversity effects on financial performance). It is just that there are far too many to try and include, as the scope of the study was to find and summarize direct relationships. Future research may include studies with moderating and mediating effects to get more dynamic insights. Finally, the metaanalysis findings are more generalizable than individual studies' results (relying on a single database). Thus, future research should consider different data sets with samples from multiple countries and other contexts to increase the validity of the findings.

This comprehensive study contributes to the business management literature in the following ways. First, we present evidence from the literature that generally supports the notion that "Doing Good is Good for Business" (Bocquet et al. 2017; Martinez-Conesa et al. 2017; Buchanan et al. 2018). Second, our work contributes to the literature on CSR and firm information environment (Cui et al. 2018; Martínez-Ferrero et al. 2016). We highlight the importance of finding the missing link between CSR and a firm's stock price informativeness. Third, this research builds on the existing CSR literature showing that CSR mitigates different types of business risks (Kim et al. 2014; Braune et al. 2019). Our contribution in this domain is to bridge the gap between CSR and financial distress risk. Finally, this research also contributes to the literature on CSR and firm access to finance (like La Rosa et al. 2018; Jiraporn et al. 2014). In this review of the literature, we did not find evidence on how CSR impacts trade credit. Our contribution in this domain will open new avenues for business management and financial management researchers. It can motivate practitioners and projects looking for an increasing amount of and dynamic set of relationships between CSR practices and financial management.

Future research could investigate how CSR's relationship with firm performance is different in the developing world than in developed nations. However, it is an essential comparison as there exist conflicting opinions amongst the two country contexts as to how they perceive CSR, based on differences in national economies, politics, and stages of implementation of the UN SDGs. In addition, further research is necessary regarding how the financial gains reaped due to a focus on CSR performance reflected on employees, supply chains, compensation, and the well-being of such firms. Lastly, future research should help determine whether becoming socially, ethically, and environmentally responsible bring about a transformative change externally in an organization's market, customers, and financial sectors.

Author Contributions: Conceptualization, A.S. and R.S.; methodology, A.S.; software, A.S.; formal analysis, A.S.; data mining, A.S.; writing—original draft preparation, R.S. and A.S.; writing-review and editing, R.S.; project administration, R.S. All authors have read and agreed to the published version of the manuscript.

Funding: This research received no external funding.

Data Availability Statement: Not applicable due to the third-party data.

Conflicts of Interest: The authors declare no conflict of interest.

\section{References}

Adhikari, Binay K. 2016. Causal effect of analyst following on corporate social responsibility. Journal of Corporate Finance 41: 201-16. [CrossRef]

Alniacik, Umit, Esra Alniacik, and Nurullah Genc. 2011. How corporate social responsibility information influences stakeholders' intentions. Corporate Social Responsibility and Environmental Management 18: 234-45. [CrossRef] 
Altman, Edward I. 1968. Financial ratios, discriminant analysis and the prediction of corporate bankruptcy. Journal of Finance 23: 589-609. [CrossRef]

Altman, Edward I., Małgorzata Iwanicz-Drozdowska, Erkki K. Laitinen, and Arto Suvas. 2016. Financial distress prediction in an international context: A review and empirical analysis of altman's z-score model. Journal of International Financial Management $\mathcal{E}$ Accounting 28: 131-71.

Attig, Najah, Sadok El Ghoul, Omrane Guedhami, and Jungwon Suh. 2013. Corporate social responsibility and credit ratings. Journal of Business Ethics 117: 679-94. [CrossRef]

Bénabou, Roland, and Jean Tirole. 2010. Individual and corporate social responsibility. Economica 77: 1-19. [CrossRef]

Bhandari, Avishek, and David Javakhadze. 2017. Corporate social responsibility and capital allocation efficiency. Journal of Corporate Finance 43: 354-77. [CrossRef]

Bocquet, Rachel, Christian Le Bas, Caroline Mothe, and Nicolas Poussing. 2017. CSR, innovation, and firm performance in sluggish growth contexts: A firm-level empirical analysis. Journal of Business Ethics 146: 241-54. [CrossRef]

Bouslah, Kais, Lawrence Kryzanowski, and Bouchra M'zali. 2013. The impact of the dimensions of social performance on firm risk. Journal of Banking and Finance 37: 1258-73. [CrossRef]

Braune, Eric, Pablo Charosky, and Lubica Hikkerova. 2019. Corporate social responsibility, financial performance and risk in times of economic instability. Journal of Management and Governance 23: 1007-21. [CrossRef]

Brine, Matthew, Rebecca Brown, and Greg Hackett. 2007. Corporate social responsibility and financial performance in the australian context. Economic Round-Up 1: 47-58.

Buchanan, Bonnie, Cathy Xuying Cao, and Chongyang Chen. 2018. Corporate social responsibility, firm value, and influential institutional ownership. Journal of Corporate Finance 52: 73-95. [CrossRef]

Cai, Li, Jinhua Cui, and Hoje Jo. 2015. Corporate environmental responsibility and firm risk. Journal of Business Ethics 139: 1-32. [CrossRef]

Cai, Ye, Carrie H. Pan, and Meir Statman. 2016. Why do countries matter so much in corporate social performance? Journal of Corporate Finance 41: 591-609. [CrossRef]

Calabretta, Giulia, Boris Durisin, and Marco Ogliengo. 2011. Uncovering the intellectual structure of research in business ethics: A journey through the history, the classics, and the pillars of Journal of Business Ethics. Journal of Business Ethics 104: 499-524. [CrossRef]

Carroll, Archie B. 1979. A three-dimensional conceptual model of corporate performance. The Academy of Management Review 4: 497-505. [CrossRef]

Cheng, Beiting, Ioannis Ioannou, and George Serafeim. 2014. Corporate social responsibility and access to finance. Strategic Management Journal 35: 1-23. [CrossRef]

Cheng, Haw, Harrison Hong, and Kelly Shue. 2013. Do Managers do Good with Other People's Money? Working Paper. Cambridge: National Bureau of Economic Research (NBER).

Chollet, Pierre, and Blaise W. Sandwidi. 2018. CSR engagement and financial risk: A virtuous circle? International evidence. Global Finance Journal 38: 65-81. [CrossRef]

Cooper, Michael J., Huseyin Gulen, and Alexei V. Ovtchinnikov. 2010. Corporate political contributions and stock returns. Journal of Finance 65: 687-724. [CrossRef]

Cui, Jinhua, Hoje Jo, and Haejung Na. 2017. Corporate social responsibility, religion, and firm risk. Asia-Pacific Journal of Financial Studies 46: 305-40. [CrossRef]

Cui, Jinhua, Hoje Jo, and Haejung Na. 2018. Does corporate social responsibility affect information asymmetry? Journal of Business Ethics 148: 549-72. [CrossRef]

Dhaliwal, Dan, Oliver ZhenLi, Albert Tsang, and Yong GeorgeYang. 2014. Corporate social responsibility disclosure and the cost of equity capital: The roles of stakeholder orientation and financial transparency. Journal of Accounting and Public Policy 33: 328-55. [CrossRef]

Dhaliwal, Dan S., Suresh Radhakrishnan, Albert Tsang, and Yong George Yang. 2012. Nonfinancial disclosure and analyst forecast accuracy: International evidence on corporate social responsibility disclosure. The Accounting Review 87: 723-59. [CrossRef]

Di Giuli, Alberta, and Leonard Kostovetsky. 2014. Are red or blue companies more likely to go green? Politics and corporate social responsibility. Journal of Financial Economics 111: 158-80. [CrossRef]

Dionisio, Marcelo, and Eduardo Raupp de Vargas. 2020. Corporate social innovation: A systematic literature review. International Business Review 29: 101641. [CrossRef]

Drago, Danilo, Concetta Carnevale, and Raffaele Gallo. 2019. Do corporate social responsibility ratings affect credit default swap spreads? Corporate Social Responsibility and Environmental Management 26: 644-52. [CrossRef]

Dreesbach-Bundy, Suska, and Barbara Scheck. 2017. Corporate volunteering: A bibliometric analysis from 1990 to 2015. Business Ethics: A European Review 26: 240-56. [CrossRef]

El Ghoul, Sadok, Omrane Guedhami, Chuck C. Y. Kwok, and Dev R. Mishra. 2011. Does corporate social responsibility affect the cost of capital? Journal of Banking and Finance 35: 2388-406. [CrossRef]

El Ghoul, Sadok, Omrane Guedhami, He Wang, and Chuck C. Y. Kwok. 2016. Family control and corporate social responsibility. Journal of Banking and Finance 73: 131-46. [CrossRef] 
Elfenbein, Daniel W., Ray Fisman, and Brian McManus. 2012. Charity as a substitute for reputation: Evidence from an online marketplace. The Review of Economic Studies 79: 1441-68. [CrossRef]

Fatemi, Ali, Iraj Fooladi, and Hassan Tehranian. 2015. Valuation effects of corporate social responsibility. Journal of Banking and Finance 59: 182-92. [CrossRef]

Feng, Zhi-Yuan, Ming-Long Wang, and Hua-Wei Huang. 2015. Equity financing and social responsibility: Further international evidence. The International Journal of Accounting 50: 247-80. [CrossRef]

Flammer, Caroline, Bryan Hong, and Dylan Minor. 2019. Corporate governance and the rise of integrating corporate social responsibility criteria in executive compensation: Effectiveness and implications for firm outcomes. Strategic Management Journal 40: 1097-122. [CrossRef]

Friedman, Milton. 2007. The social responsibility of business is to increase its profits. In Corporate Ethics and Corporate Governance. Edited by Zimmerli Walther Ch, Klaus Richter and Markus Holzinger. Berlin/Heidelberg: Springer, pp. 173-78.

Galbreath, Jeremy. 2018. Is board gender diversity linked to financial performance? The mediating mechanism of CSR. Business $\mathcal{E}$ Society 57: 863-89.

Galema, Rients, Auke Plantinga, and Bert Scholtens. 2008. The stocks at stake: Return and risk in socially responsible investment. Journal of Banking and Finance 32: 2646-54. [CrossRef]

Gamerschlag, Ramin, Klaus Möller, and Frank Verbeeten. 2011. Determinants of voluntary csr disclosure: Empirical evidence from germany. Review of Managerial Science 5: 233-62. [CrossRef]

García-Sánchez, García-Sánchez, Nazim Hussain, Jennifer Martínez-Ferrero, and Emiliano Ruiz-Barbadillo. 2019. Impact of disclosure and assurance quality of corporate sustainability reports on access to finance. Corporate Social Responsibility and Environmental Management 26: 832-48. [CrossRef]

Gelb, David S., and Joyce A. Strawser. 2001. Corporate social responsibility and financial disclosures: An alternative explanation for increased disclosure. Journal of Business Ethics 33: 1-13. [CrossRef]

Goss, Allen, and Gordon S. Roberts. 2011. The impact of corporate social responsibility on the cost of bank loans. Journal of Banking and Finance 35: 1794-810. [CrossRef]

Groening, Christopher, and Vamsi K. Kanuri. 2016. Investor reactions to concurrent positive and negative stakeholder news. Journal of Business Ethics 149: 833-56. [CrossRef]

Haggard, K. Stephen, Xiumin Martin, and Raynolde Pereira. 2008. Does voluntary disclosure improve stock price informativeness? Financial Management 37: 747-68. [CrossRef]

Harjoto, Maretno Agus, and Fabrizio Rossi. 2019. Religiosity, female directors, and corporate social responsibility for Italian listed companies. Journal of Business Research 95: 338-46. [CrossRef]

Harris, Jared D., Harry J. Sapienza, and Norman E. Bowie. 2009. Ethics and entrepreneurship. Journal of Business Venturing 24: 407-18. [CrossRef]

Hemingway, Christine A., and Patrick W. Maclagan. 2004. Managers' personal values as drivers of corporate social responsibility. Journal of Business Ethics 50: 33-44. [CrossRef]

Herremans, Irene M., Parporn Akathaporn, and Morris McInnes. 1993. An investigation of corporate social responsibility reputation and economic performance. Accounting, Organizations and Society 18: 587-604. [CrossRef]

Hong, Harrison, Jeffrey D. Kubik, and Jose A. Scheinkman. 2012. Financial Constraints on Corporate Goodness. Working Paper. Cambridge: National Bureau of Economic Research (NBER).

Humphrey, Jacquelyn E., Darren D. Lee, and Yaokan Shen. 2012. Does it cost to be sustainable? Journal of Corporate Finance 18: 626-39. [CrossRef]

Husted, Bryan W. 2005. Risk management, real options, corporate social responsibility. Journal of Business Ethics 60: 175-83. [CrossRef]

Jamali, Dima, and Archie Carroll. 2017. Capturing advances in CSR: Developed versus developing country perspectives. Business Ethics: A European Review 26: 321-25. [CrossRef]

Jiraporn, Pornsit, Napatsorn Jiraporn, Adisak Boeprasert, and Kiyoung Chang. 2014. Does corporate social responsibility (csr) improve credit ratings? Evidence from geographic identification. Financial Management 43: 505-31. [CrossRef]

Jo, Hoje, and Haejung Na. 2012. Does csr reduce firm risk? Evidence from controversial industry sectors. Journal of Business Ethics 110: 441-56. [CrossRef]

Jones, David A., Alexander Newman, Ruodan Shao, and Fang Lee Cooke. 2019. Advances in employee-focused micro-level research on corporate social responsibility: Situating new contributions within the current state of the literature. Journal of Business Ethics 157: 293-302. [CrossRef]

Kaplan, Steven N., and Luigi Zingales. 1997. Do investment-cash flow sensitivities provide useful measures of financing constraints? The Quarterly Journal of Economics 112: 169-215. [CrossRef]

Kim, Yongtae, Haidan Li, and Siqi Li. 2014. Corporate social responsibility and stock price crash risk. Journal of Banking and Finance 43: 1-13. [CrossRef]

Kim, Yongtae, Myung Seok Park, and Benson Wier. 2012. Is earnings quality associated with corporate social responsibility? The Accounting Review 87: 761-96. [CrossRef]

Kölbel, Julian F., Timo Busch, and Leonhardt M. Jancso. 2017. How media coverage of corporate social irresponsibility increases financial risk. Strategic Management Journal 38: 2266-84. [CrossRef] 
KPMG. 2013. The KPMG Survey of Corporate Responsibility Reporting 2013. Available online: http://www.kpmg.com/global/ en/issuesandinsights/articlespublications/corporate-responsibility/pages/corporate-responsibility-reporting-survey-2013 (accessed on 25 June 2019).

Kramer, Mark R., and Michael E. Porter. 2011. Creating shared value. Harvard Business Review 17: 1-17.

Krüger, Philipp. 2015. Corporate goodness and shareholder wealth. Journal of Financial Economics 115: 304-29. [CrossRef]

La Rosa, Fabio, Giovanni Liberatore, Francesco Mazzi, and Simone Terzani. 2018. The impact of corporate social performance on the cost of debt and access to debt financing for listed European nonfinancial firms. European Management Journal 36: 519-29. [CrossRef]

Lee, Darren D., and Robert W. Faff. 2009. Corporate sustainability performance and idiosyncratic risk: A global perspective. Financial Review 44: 213-37. [CrossRef]

Lee, Changhee, Dan Palmon, and Ari Yezegel. 2018. The corporate social responsibility information environment: Examining the value of financial analysts' recommendations. Journal of Business Ethics 150: 279-301. [CrossRef]

Lins, Karl V., Henri Servaes, and Ane Tamayo. 2017. Social Capital, Trust, and Firm Performance: The Value of Corporate Social Responsibility during the Financial Crisis. Journal of Finance 72: 1785-824. [CrossRef]

Long, Wenbin, Sihai Li, Huiying Wu, and Xianzhong Song. 2019. Corporate social responsibility and financial performance: The roles of government intervention and market competition. Corporate Social Responsibility and Environmental Management 27: $252-541$. [CrossRef]

Lys, Thomas, James P. Naughton, and Clare Wang. 2015. Signaling through corporate accountability reporting. Journal of Accounting and Economics 60: 56-72. [CrossRef]

Mackey, Alison, Tyson B. Mackey, and Jay B. Barney. 2007. Corporate social responsibility and firm performance: Investor preferences and corporate strategies. The Academy of Management Review 32: 817-35. [CrossRef]

Malik, Mahfuja. 2015. Value-enhancing capabilities of CSR: A brief review of contemporary literature. Journal of Business Ethics 127: 419-38. [CrossRef]

Margolis, Joshua D., Hillary Anger Elfenbein, and James P. Walsh. 2009. Does It Pay to be Good ... And Does it Matter? A Meta-Analysis of the Relationship between Corporate Social and Financial Performance. Working Paper. Available online: https: / / ssrn.com/abstract=1866371 (accessed on 26 March 2020). [CrossRef]

Margolis, Joshua D., and James P. Walsh. 2003. Misery loves companies: Rethinking social initiatives by business. Administrative Science Quarterly 48: 268-305. [CrossRef]

Martinez-Conesa, Isabel, Pedro Soto-Acosta, and Mercedes Palacios-Manzano. 2017. Corporate social responsibility and its effect on innovation and firm performance: An empirical research in SMEs. Journal of Cleaner Production 142: 2374-83. [CrossRef]

Martínez-Ferrero, Jennifer, David Ruiz-Cano, and Isabel-María García-Sánchez. 2016. The causal link between sustainable disclosure and information asymmetry: The moderating role of the stakeholder protection context. Corporate Social Responsibility and Environmental Management 23: 319-32. [CrossRef]

Martínez-Ferrero, Jennifer, Isabel M. Garcia-Sanchez, and Beatriz Cuadrado-Ballesteros. 2015. Effect of financial reporting quality on sustainability information disclosure. Corporate Social Responsibility and Environmental Management 22: 45-64. [CrossRef]

Masulis, Ronald W., and Syed Walid Reza. 2015. Agency problems of corporate philanthropy. The Review of Financial Studies 28: 592-636. [CrossRef]

McCarthy, Scott, Barry Oliver, and Sizhe Song. 2017. Corporate social responsibility and ceo confidence. Journal of Banking and Finance 75: 280-91. [CrossRef]

McWilliams, Abagail, and Donald Siegel. 2001. Corporate social responsibility: A theory of the firm perspective. The Academy of Management Review 26: 117-27. [CrossRef]

Mishra, Saurabh, and Sachin B. Modi. 2013. Positive and negative corporate social responsibility, financial leverage, and idiosyncratic risk. Journal of Business Ethics 117: 431-48. [CrossRef]

Pava, Moses L., and Joshua Krausz. 1996. The association between corporate social-responsibility and financial performance: The paradox of social cost. Journal of Business Ethics 15: 321-57. [CrossRef]

Pope, S., and A. Wæraas. 2016. CSR-washing is rare: A conceptual framework, literature review, and critique. Journal of Business Ethics 137: 173-93. [CrossRef]

Sardana, Deepak, Narain Gupta, Vikas Kumar, and Mile Terziovski. 2020. CSR' sustainability'practices and firm performance in an emerging economy. Journal of Cleaner Production 258: 120766. [CrossRef]

Servaes, Henri, and Ane Tamayo. 2013. The impact of corporate social responsibility on firm value: The role of customer awareness. Management Science 59: 1045-61. [CrossRef]

Shafai, Nor Atikah Binti, Azlan Bin Amran, and Yuvaraj Ganesan. 2018. Earnings management, tax avoidance and corporate social responsibility: Malaysia evidence. Management 5: 41-56. [CrossRef]

Shapiro, Susan P. 2005. Agency theory. Annual Review of Sociology 31: 263-84. [CrossRef]

Sroufe, Robert. 2018. Integrated Management: How Sustainability Creates Value for Any Business. Bradford: Emerald Group Publishing.

Sun, Wenbin, and Kexiu Cui. 2014. Linking corporate social responsibility to firm default risk. European Management Journal 32: 275-87. [CrossRef] 
The Paris Agreement I UNFCC. 2016. Available online: https:/ / unfccc.int/process-and-meetings/the-paris-agreement/the-parisagreement (accessed on 15 January 2021).

Ting, Pi-Hui. 2020. Do large firms just talk corporate social responsibility? The evidence from CSR report disclosure. Finance Research Letters 38: 101476. [CrossRef]

Trapp, N. Leila. 2012. Corporation as climate ambassador: Transcending business sector boundaries in a Swedish CSR campaign Public Relations Review 38: 458-65. [CrossRef]

Verwijmeren, Patrick, and Jeroen Derwall. 2010. Employee well-being, firm leverage, and bankruptcy risk. Journal of Banking and Finance 34: 956-64. [CrossRef]

Vishwanathan, Pushpika, Hans van Oosterhout, Pursey P. M. A. R. Heugens, Patricio Duran, and Marc Van Essen. 2020. Strategic CSR: A concept building meta-analysis. Journal of Management Studies 57: 314-50. [CrossRef]

Waddock, Sandra A., and Samuel B. Graves. 1997. The corporate social performance-financial performance link. Strategic Management Journal 18: 303-19. [CrossRef]

Wanderley, Lilian Soares Outtes, Rafael Lucian, Francisca Farache, and José Milton de Sousa Filho. 2008. CSR information disclosure on the web: A context-based approach analysing the influence of country of origin and industry sector. Journal of Business Ethics 82: 369-78. [CrossRef]

Wright, Peter, and Stephen P. Ferris. 1997. Agency conflict and corporates strategy: The effect of divestment on corporate value. Strategic Management Journal 18: 77-83. [CrossRef]

$\mathrm{Wu}$, Meng-Wen, and Chung-Hua Shen. 2013. Corporate social responsibility in the banking industry: Motives and financial performance. Journal of Banking and Finance 37: 3529-47. [CrossRef] 